\title{
Carter juggles with fast breeder and natural gas
}

\section{John Douglas discusses how President Carter has managed to enrage combatants on all sides of the fast breeder issue}

PRESIDENT Carter has further entangled himself in the meshes of his energy bill - this time through an unlikely deal linking the price of natural gas with research on the fast breeder reactor.

Carter's proposals for price controls on natural gas had been bottled up in a Congressional conference committee for six months, and to free the gas bill for consideration by the full Senate, he needed one more Republican signature on the conference report. So he invited Senator James A McClure of Idaho to the White House to discuss a compromise. Both parties deny actually making a 'deal', but McClure signed the conference report and an-
Schlesinger also committed the Administration to building the Safety Research Experiment Facility (SAREF), the Fuels and Materials Evaluation Facility (FUMEF) and the High Performance Fuel Laboratory (HPFL) - all of which the President had earlier opposed as part of his policy to shift from "early commercialisation to long-range technical development" of the breeder.

Finally came the matter of the Clinch River Breeder Reactor (CRBR), the costly and controversial demonstration project Carter has opposed since early in his election campaign. Schlesinger wrote that the project would be "discontinued" — without

\section{Sorry, for copyright reasons some images on this page may not be available online}

White House meeting: President Carter, Senator McClure, Energy Secretary Schlesinger.

nounced that he had received assurances from the White House that increased funds for a large breeder reactor no longer faced a Presidential veto. Presumably, some of these reactor funds would find their way to the Idaho National Engineering Laboratory, which has long experience in the breeder field.

Details of the understanding reached on the breeder issue were confirmed in a letter from Energy Secretary James Schlesinger, who also attended the White House meeting. The Administration, he said, would no longer oppose development of a conceptual design for an "improved demonstration project" of the plutonium breeder reactor, although the size was not specified. To fund the entire breeder program $\$ 513$ million would be appropriated for fiscal year 1979 , \$504 million for FY 1980, and $\$ 520$ million for FY 1981. (The Administration had originally wanted to cut back such funding to about $\$ 400$ million for the next fiscal year, but the House had already defeated that proposal.) specifying whether that meant "cancelled" (the earlier wording of Adminis ration policy) or merely "deferred." Some components of the CRBR would be completed and tested, and some of the preliminary licensing would be conducted. A final decision on whether to build this or another large breeder reactor would then be made by 1982

At first the compromise looked as if it might work. The Administration had overcome a major hurdle facing an important piece of legislation by giving in on a point on which it had already suffered a partial defeat. But in the process of hammering out this compromise, the President and his advisers committed the sort of political blunder that has too often marked the Administration's dealings with Congress: they ignored the Senate Republican leader Howard $\mathrm{H}$ Baker $\mathrm{Jr}$ of Tennessee.

Under any circumstances, Senator Baker's cooperation would have been important to the ultimate passage of the natural gas bill, for the President faces too much opposition within his own party on the issue to ignore the Republican votes Baker can influence. But more important, the compromise suggested to Baker that even if a large breeder reactor were finally authorised, the chances of building it at Clinch River, Tennessee, had been diminished.

Faced with a tough election campaign for his own Senate seat this fall, Baker reacted angrily to what he saw as a personal slight and a threat to a billion-dollar project in his home state. He announced that unless the status of the Clinch River project were cleared up he would no longer support the natural gas bill, which faces strong opposition from a small but determined group of Senators. Without his apparently vital support to cut off debate, under the rules of the Senate a minority of members might well be able to kill the bill by filibustering.

The issue of natural gas deregulation is by far the most complex and controversial section of the National Energy Act finally released by House and Senate conferees. The other three sections - dealing with energy conservation, conversion of power plants from oil to coal, and reform of utility rates - will probably pass easily, but none is likely to have the international impact of the natural gas bill, whose purpose is to lower American oil imports by substituting domestically produced gas.

The conference committee report is the latest salvo in a 39-year confrontation between producers and consumers over government control of gas prices. If enacted, the new law would eliminate the distinction between gas sold within a state and that sold between states. The two categories are now controlled differently. The bill provides that newly discovered gas in both catagories would be allowed to escalate in price somewhat more rapidly than inflation until 1985 , when all price controls would be removed.

The argument in favour of this loosening of control is that creation of a single gas market will make more gas available to interstate buyers, encouraging them to substitute gas for imported oil. At the same time, this argument goes, rising prices will encourage producers to step up exploration for more new gas. The Department of Energy estimates that by 1985 , the equivalent of one million barrels per day of imported oil will have been replaced by domestic gas, representing a 10 percent reduction in total imports, at a $\$ 5$ billion annual savings.

Opponents of the gas bill argue that higher prices will only fuel inflation and that recent history indicates that 
gas companies will not rush out to drill more wells just because prices are rising. A Chase Manhattan Bank study of the question concluded that "the legislation could actually result in some weakening of the dollar as foreign exchange markets come to perceive that the long-run supply of natural gas in the U.S. is as likely to be reduced as increased." And at least two senators have announced plans to oppose the bill because of their opposition to breeder reactors, now linked to it.

The Carter-McClure compromise is also likely to broaden the debate over conduct of the entire breeder reactor programme. Work is still not complete on the Fast Flux Test Facility, (FFTF) a non-power-generating breeder reactor meant to be a forerunner of Clinch River. First authorised in 1967, FFTF was originally estimated to cost only $\$ 87.5$ million but has already passed the billion dollar mark. The CRBR has also experienced severe delays and cost overruns, and both industry and Congressional sources tell Nature that any further delay would probably result in a re-evaluation of the basic American breeder design.

During the debate over whether breeder reactors should be built at all, many technologists have reportedly swallowed their specific objections to the CRBR design in hopes of not exacerbating the issue. Specifically, they favour a reactor in which the radioactive molten sodium that passes through the core never leaves the re- actor vessel and one in which steam for generating electricity is handled at a lower temperature and pressure than now called for. If the Clinch River project is deferred or cancelled in favour of producing a later-and probably larger-reactor, such arguments will probably become much more audible.

It is hard to recall a time when the US energy picture has appeared more cloudy. After he had calmed his initial anger, about the best Senator Baker could say for the recent compromise was "the water has been muddied". All that remains certain is that both the natural gas regulation and breeder reactor issues will take on new dimensions when Congress returns from its present Labour Day recess.

\section{Boycott of Soviet contacts is for individuals, says NAS}

RECENT 'human rights' trials of scientists in the Soviet Union resulted in the immediate cancellation of several major visits by US scientists to the Soviet Union-and these in turn have provoked a biting reaction from the Soviet media-a sure sign that the threat of a severance of scientific relations was a real one. "Future historians will be amazed" wrote the Literaturnaya Gazeta, that such reprisals could be contemplated as a means of making the USSR give up "the principles which are sacred to it."

This reaction would appear to sub stantiate the case for boycott, a case most ably put by Valentin Turchin (Nature 273, 256-257; 1978). Not all scientists would support this view, feeling that continuation of contacts makes it possible to express one's concern with the fate of, say, Orlov and Shcharanskii, at least on the personal level, to Soviet colleagues encountered at international conferences.

Thus last month, when the Inter. national Congress of Mathematicians was held in the "human rights" city of Helsinki, right on the Soviets' doorstep (subsidised excursions to Leningrad were laid on as a side attraction), several Soviet mathematicians failed to arrive to deliver their papers. One of these people, a Dr Margulis, was scheduled to receive a medal. The ceremony was carried out in his absence, and the formal "presentation" of his work was greeted by a standing ovation, pinpointing in a telling manner the persistent Soviet practice of denying visas to scientists invited to international conferences.

Many would see the stricter insistence on the norms of scientific lifeincluding proper representation at con- ferences, a more fitting form of protest than an all-out or selective boycott.

Respecting the diversity of views on boycott, the US National Academy of Sciences recently put out a statement calling on world scientists to urge the release of Orlov, Shcharanskii and Sergei Kovalev, a biologist now halfway through a sentence of seven years in a labour camp. The Human Rights Committee of the Academy said:

"These scientists, along with fourteen others in other parts of the world, are of particular concern to this committee, for they represent numbers of colleagues who believe that freedom of intellectual inquiry cannot be divided into two parts-one for the natural world in which we live and one for the society which nurtures us-and who have been imprisoned for acting in accordance with their beliefs".

Nevertheless, the Academy stressed that it does not, as a body, endorse boycotts. "Each American scientist", it concludes, "contemplating a visit to the USSR (or asked to host a Soviet scientist in the US) must determine his or her own course of action."

Interestingly, this decision follows an opposite course to that advocated by a group of French physicists last July, who advocated the severance of all official scientific relations-including conferences-while maintaining personal contacts with Soviet colleagues, making the latter the "occasion of expressing our indignation".

The NAS acceptance of individual choice of protest also underlies the concluding paragraph of a moving appeal which recently reached the West from Kovalev's son, Ivan. Addressing the intending participants of the Fourteenth International Congress of
Genetics in Moscow, he outlined the history of his father's case, and gave a vivid and horrifying picture of prison conditions, he asked for the participants' support, that they would express their attitude towards the imprisonment of their colleague "by means appropriate to you". The appeal has since been circulated by campaigners for boycott, but it is noteworthy that neither Amnesty International, who distributed the letter, nor Ivan Kovalev himself, specifically ask for this.

Nevertheless, the idea of at least a selective boycott does seem to be taking hold in the USA. According to the NAS, its supporters "include scientists who pioneered in the earliest Soviet/ US exchanges, seeking to build bridges of common scientific endeavour across the chasm of the cold war. They also include others who have seen themselves as steadfast in resisting the politicisation of science. People have reached their decisions in varied ways: sadness, rather than anger has been the most common emotion".

It is because the response of US scientists is so "individualistic", concludes the Academy, that continued Soviet-US scientific relations are in peril. "Scientific exchange programmes" it says "can be negotiated and organised, but individual participation cannot be commanded. There has been no institutional instruction or decision making. no rush to judgment, and no stampede to boycott. Rather there is a tide of spontaneous response running deep, and it will not be easily reversed in the absence of some iudicious and humanitarian actions by Soviet authorities".

Vera Rich 